\title{
Russian Legislation on Security Interest: Important Changes
}

\author{
Mariya Anatolevna Kovaleva \\ Olga Nikolaevna Kichalyuk \\ Oksana Alaxandrovna Morozova
}

Don State Technical University

Email: derbentsevamasha@mail.ru

\section{Doi:10.5901/mjss.2015.v6n2p22}

\begin{abstract}
In 2013 an important reform of civil legislation was performed in the Russian Federation. The reform was performed in 3 steps by passing the laws amending the Civil Code of the Russian Federation (hereinafter - the Russian Civil Code) within the year 2013. As a result, the Russian legislature has changed and greatly enhanced Civil Code and, particularly, legislation on security. Today the Russian Civil Code includes a chapter on obligations, which contains an expanded and sophisticated section on "security interest". Thus in our article we have reviewed the main steps of the Russian Civil legislation Reform. Particularly, we have identified the main reasons of this reform. However, in this article we have analyzed the provisions on security interest more detail. In our article we reviewed the main law changes on security interest, which have been introduced since 2008.
\end{abstract}

Keywords: security right, security interest, obligation, agreement;

\section{Introduction}

What is zalog in Russia? Many lawyers translate "zalog" as "collateral" " $\{$ collateral security\}, security for the performance of covenants, or the payment of money, besides the principal security" (see, e.g., What is The Difference Between Collateral and Mortgage, 2014)), as "lien" ("a right to keep possession of property belonging to another person until a debt owed by that person is discharged" (Oxford Dictionaries, 2014)). In scholarly commentary in English the Russian word "zalog" is translated almost uniformly as "pledge" see, e.g., Frenkel, W.G. (1993) ("to deposit personal property as security for a personal loan of money. If the loan is not repaid when due, the personal property pledged shall be forfeit to the lender" (Search Legal Terms and Definitions, 2014)). But, it is more accurately to translate the word "zalog" as "security interest" ("generic term for the property rights of a lender or creditor whose right to collect a debt is secured by property" (Search Legal Terms and Definitions, 2014)), as it clearly encompasses much more than the narrow historical connotation of the word "pledge", which involves an obligatory transfer of collateral to the secured creditor (a transaction described more accurately by the Russian word "zaklad" Kilborn, J.J. (1995). In this article we will use "security interest" as "zalog" and "mortgage" as "ipoteka".

Security interest appears in a variety of contexts, but most in the loan transactions on an obligation to return borrowed funds. When a consumer purchases a car with money borrowed from a bank or from an automobile financier or when a factory acquires a loan from a financial institution to expand its operations, the lender desires more assurance than simply the good word of the borrower that the money will be returned. Therefore, the lender takes security interest in an item of a value equal to or greater than the amount of the debt, for instance, in the examples mentioned above, of the car or of the equipment or inventory of the factory. If the borrower fails to make interest payments or to repay the loan according with agreement (in other words, if the borrower "defaults"), the security interest provides a basis for the lender to go and take the asset acting as security (to repossess or "foreclose on the security interest") and dispose of it to satisfy the repayment obligation (see, e.g., art. 334 the Russian Civil Code)). It should be clear that if the creditor cannot effectively enforce security interest and dispose of the security interest, the entire effort to secure the debt has been for naught, Kilborn, J.J. (1995).

The history of security rights traces its roots back to remote past. This instrument was known in Ancient Rome where two forms of the security right were distinguished - "pignus", Zimmermann, R. (1990) and "hypoteca". Since that time security rights have not lost its sense, though there may be some differences in its legal regulation. In common law it 
is a collateral or a mortgage, in German law - pfand and grundpfand, in French - gage and hypothèque, in Russian law zalog and ipoteka. Because of diversity of security rights in the world, many law scholars research security right see, e.g., Bazinas, S.V. (2011); Akseli, N.O. (2011); Andenas, M. and C. B. Andersen, eds. (2011); Beale, H. and others, (2012).

In France an agreement on security right is an agreement by which a debtor provides to a creditor the right to satisfy his claim as an asset over other creditors from one or more movable assets in the material form, including from the future movable asset (art. 2333 French Civil Code). The French Civil Code distinguishes a pledge of property in the material form (art. 2355), «antichresis» (art. 2387) and a mortgage (art. 2393). In Germany the security rights is not an obligation, but a limited proprietary right. According to the German Civil Code there are the pledge of the movable property and the mortgage (the pledge of the immovable asset with the certain restrictions) $(\S 232,238)$. A secured asset can be transmitted to the creditor as satisfaction an obligation (Pfandrecht an Rechten) (§ 232).

In Russia security interest was widely applied before the Revolution of 1917. In Soviet times the sphere of security interest usage was rather small and it regulation was very poor. For example, there was no such institution as hypothec at all (security interest in the form of immovable asset). The institution of security interest of immovable asset was revived in 1992 by the enactment of the Law on security interest. The appropriate provisions were included in the Russian Civil Code in 1995, the Federal Law on Mortgage was enacted in 1998.

When a debtor does not render a security obligation, a creditor may satisfy their claim from a secured asset. It is the main peculiarity of Russian security interest. The creditor only receives the right to cover the debt from the value of secured asset in case of debtor's default by levy of execution upon secured asset. Generally, judicial procedure is required for foreclosure on the secured asset as security interest. However, in some cases extrajudicial enforcement procedure is allowed to.

Commonly a secured asset is located in the possession and usage of a debtor. However, such practice is not admitted in some countries where a secured asset is always conveyed to a creditor (possessory security interest). Often a debtor is not an owner of the secured asset as security interest. It may be another person or legal entity (e.g., a company affiliated with a debtor pledges own asset to secure debtor's obligation). In such case a third participant is pledger. It a participant of relationships of security interest to (Collateral in Russia, 2014).

Thus, the concept of security rights in Russia is differs from other foreign security rights concept.

While the new provisions on security interest have the potential to assure lenders of the security of their investments, and thus to stimulate greater flow of capital into Russian enterprises, several shortcomings might head off the effective achievement of the goals which underlie these provisions. This article focuses on the main positive changes in Russian law on security interest.

\section{Russian Civil Legislation Reform}

Any effective security interest system draws the lenders to part with their capital temporarily, but it must allow secured the creditors to feel reasonably assured that they would be able ultimately to regain their investments. Although, the secured creditors wish to avoid foreclosure and satisfaction from the security rights as much as the debtors do, they must have confidence that the system will provide them acceptable means of a capital return if eventually they are forced to foreclose on the collateral to avoid a loss.

The Russian Civil legislation system has developed sufficiently. However, a market develops faster than the Russian Civil legislation. It is a reason of the many economic crimes. In this situation law is incomplete in some classic civil institutions, such as the invalidity of transactions, the creation of the Legal Entities, reorganization of the Legal Entity, liquidation of the Legal Entity, assignment, security interest, etc. In the Russian Civil legislation the diversity of legal norms and legal means were predetermined by the freedom of the economic behavior of the participants of the civil matters. However, many of the general provisions of the Russian Civil Code required some change. The absence some general rules of the Russian Civil Code would not compensated by the judicial interpretations.

Moreover, the intensive development of economy and financial markets required the development of the legislation on securities and financial transactions. As the result, the necessity of the reforming of the Russian Civil Code, including the first part (the first part of the Russian Civil Code defines the general provisions and principles of the Civil Law and determines the general and the most important regulations of the Civil law), has appeared.

The changings at Russian Civil legislation were started by an initiative of the Russian President dated July 18, 2008. The changings at Russian Civil legislation affect different aspects of legal activity. In particular, law on security interest has been changed significantly since 2008 .

A project of the amendments to Russian Civil Code had been created after the initiative of the Russian President. Later, on April 13, 2012 the project of the Federal law No 47538-6 had been referred to the State Duma of the Russian 
Federation for consideration. Eventually, it was divided into several pats. The amendments of the Russian Civil Code have been changing different Federal laws since 2013.

On December 30, 2012, the President of the Russian Federation Vladimir Putin approved the proposed amendments to the Russian Civil Code by signing Federal Law No 302-FZ, which taken effect on March 1, 2013, and the Russian Civil reform has started.

Federal Laws, such as, the Federal law № 100-\$3 dated May 7, 2013, the Federal law No 142-\$3 dated July 2, 2013, the Federal law No 260-Ф3 dated September 30, 2013, and Federal law No 367-Ф3 dated December 21, 2013 have introduced amendments to the Russian Civil Code.

The current reform of the Russian Civil legislation is analyzed by Russian see, a.g., Rybalov, A.O. (2013); Cheremnyh, G.G. (2009); Stepanchenko A.V. (2013); Oskina, I.Y. and A.A. Lupu (2012); Kopylov, O.B. (2014); Buligin, A., V. Rogachev (2014) and foreign see, a.g., Tetiouchev, D. and D. Shaklein (2014); Amendments to the Russian Civil Code (2014); Brian L.Z., and D.A. Kunitsa (2014.) scholars and lawyers.

It should be noted, the civil legislation in 2013-2014 has many significant amendments (see, a.g., Amendments to the Russian Civil Code, 2014). However, in this article we will research the impact of the Russian Civil legislation reform on security interest in Russia.

\section{Reforming Russian Legislation on Security Interest}

Since 2008 law on security interest has been detailed and has been improved. For example, law on mortgage, mortgage registration, law on disposal of secured asset had been changed until 2011. That is to say, some legislative acts had been changed before the Russian Civil legislation Reform. Some provisions on security interest are changing now.

Next changes in the law on security interest have been going during the reform of the Russian Civil Law.

The chapter 23 of the Russian Civil Code regulates the securing right to performance of an obligation, which was amended by Federal Law No 367-FZ dated December 21, 2013 (the amendments entered into force on July 1, 2014).

We analyzed the most important of them.

1. Secured obligations are described simply by reference to the secured agreements. Participants are not required to specify the secured obligations in details, as it was previously required.

The participants of security interest of the movable assets may describe this asset in any way, which allows identifying such assets at the time of enforcement. Thus, since 1 January 2015 it will be possibility to give is a security interest all assets, or a part of those assets, or certain nature or type assets. For identification of such property it is sufficient to indicate only genus or species of such asset in the security interest agreement. The secured asset shall be identified at the time of execution it. Earlier, the courts could to recognize such security interest agreement not concluded, because the individual characteristics of the secured assets were not determined.

2. A secured creditor must insure an encumbered asset by the secured creditor unless otherwise provided in a security interest agreement.

3. Security interest of a movable asset can be registered in a special register operated by the notaries voluntarily. Priority is determined in accordance with the order of registration. S.A. Gromov argues that the creation of the public registers is a solution to practical problems Gromov, S.A. (2013).

The provisions on the state registration of mortgage agreements do not apply in the Russian Federation since July 1, 2014. Today mortgage is registered, not the contract (if the agreement do not establish otherwise). In cases provided by law, the limitation of title and the encumbrance of the asset (encumbrance of the property rights) will be subject of the state registration.

4. Law amendments at security interest introduced the security interest of a bank account (zalog bankovskogo schyota). The nature of "non-cash money" does not prevents applying the rules on the security interest of things to "non-cash money". Therefore, today a security interest of the money under a bank account is not possible in Russia. Special regulation on security interest of the rights under the bank account has been established in 2014. The owner of a secured asset may choose to take security over all or any part of the funds held in the account. The owner of a secured asset may not close the account without the consent of the lender, or deal with the account in a manner inconsistent with the security interest agreement.

It is worth mentioning that, that the general rules on security interest are not applied to security interest of a bank account rights.

5. The legislator has systematized the existing legal rules on security interest. As a result, today the chapter 23 of the Russian Civil Code includes seven specific types of security interest, including security interest of the 
contractual rights (zalog obyazatelstvennykh prav) as an individual type of security interest.

6. Today the lenders may to appoint a security interest manager. The scope of the security interest manager's powers would be outlined in a security interest management agreement between the lenders.

7. There is possible to provide subsequent security interest (posleduyushchiy zalog). Unlike in previous legislation the current law provides that a subsequent security interest may not be prohibited by the previous agreement of security interest. However, the previous creditor may create obligate provisions for the subsequent security interest agreement. In practice these means that previous creditor can create restrictions on subsequent creditors so that existence of those subsequent creditors become almost impossible without consent of the previous creditor.

8. The amendments introduced priority of security interest. A date of registration is the crucial factor in determining priority (do not date of signing of a security interest agreement between the co-creditors ${ }^{1}$ ), unless otherwise is not specified by the security interest agreement.

9. The participants may establish the future security interest ${ }^{2}$. The changes in 2014 have concretized norms on the future security interest. Future secured asset is a future right from an existing or a future obligation.

We can conclude that the modernization of Russian law is directed on systematization of Russian Civil law and its harmonization with the international law. Contract freedom principle is implemented.

\section{Concluding Remarks}

Aforementioned amendments to the Russian Civil Code aimed at filling the gaps in the law. Numerous amendments at security interest are aimed at improvement of the previous legislation and introduction new rules on security interest.

Definitely, the fact, that the participants are not required to specify the secured obligations in details, as it was previously required, is a very important amendment. This is particularly relevant to third party security, as incomplete description of the secured obligations was sometimes used to challenge the validity of security interest agreements.

Today there is a possibility to give to security interest all assets belonging to a debtor, or a part of these assets, or the assets of certain nature or type. However, this concept is not well developed in Russian law yet, and may be further clarified by the court practice.

As for security interest manager, it is too early to tell with any certainty how this will impact the lending market in Russia, but conceptually it should add some benefit to multiple creditors taking security over a single asset or class of assets.

The subsequent security interest is one the main innovations too. In practice this means that previous creditor can create restrictions on subsequent creditors so that existence of those subsequent creditors become almost impossible without consent of the previous creditor.

Amendments at law on security interest establish the security interest of all asset. It will be possibility since January 1, 2015. It is sufficient to indicate only genus or species of such asset in the security interest agreement for identification of such asset. The secured asset shall be identified at the time of execution it. Earlier, the courts could to recognize such security interest agreement not concluded, because the individual characteristics of the secured assets were not determined.

The amendments to Civil legislation were minimized the practice problems. In particular, amendments to law on security interest expanded the security interest concept.

\section{References}

Akseli, N.O., 2011. International secured transactions law: facilitation of credit and international conventions and instruments. London: Routledge, pp: 311.

Amendments to the Russian Civil Code: legal entities. Date Views 16 November 2014 www.lidings.com/eng/legalupdates2?id=121;

Andenas, M. and C. B. Andersen, eds., 2011. Theory and practice of harmonisation. Cheltenham, U.K., Edward Elgar, pp: 617. Selected contents: International harmonisation of credit and security laws: the way forward / N. O. Akseli

Bazinas, S.V., 2011. Law Applicable to Security Right in Movable Assets under the UNCITRAL Legislation Guide on Secured Transaction. Banking \& Finansial Policy Report, 6(Volume 30): 1-22.

Beale, H. and others, 2012. The law of security and title-based financing. 2nd ed. Oxford, Oxford University Press, pp: 821 p. Selected

1 Secured asset may be in a security interest of the several persons. These persons have equal seniority rights on this secured asset (co-creditor) in the enforcement of the different liabilities.

${ }^{2} \mathrm{~A}$ security interest agreement has created already, but a secured asset has not. 
contents: Conflict of laws, 22: 669-742.

Brian L.Z., D.A. Kunitsa, 2014. Amendments to Russian Civil Code Related to Immovable Property. Morgan Lewis.

Buligin, A., V. Rogachev, 2014. Important changes to Russian law and next steps for lenders with existing security. New Russian pledge rules. Herbert Smith Freehills, 1-8.

Cheremnyh, G.G., 2009, Novoe zakonodatelstvo v svete pravoprimenitelnoy notarialnoy praktiki: plyusy i minusy. Notapius, 5: 2-9;

Collateral in Russia: Recent Developments. Date Views 16 November 2014 www.sirotamosgo.ru/news/crrd/.

Frenkel, W.G., 1993.New Russian Secured Transactions Regime: Analysis of the Law on Pledge. SEEL,1.

Gromov, S.A., 2013. Publichnyy reestr denezhnykh obyazatelstv kak istochnik dokazatelstv besspornosri trebovaniya dlya tseley uskorennogo vzyskaniya zadolzhnosti po ispolnitelnoy nadpisi notariusa i v ramkakh uproshchennogo cudoproizvodstva. Problemy registratsii prav, fiksatsii i udostovereniya yuridicheskikh faktov grazhdanskogo prava: sbornik statey. Statut, pp: 336.

Kilborn, J.J., 1995. Securing Russia's Future: A Plea for Reform in Russian. Michigan Law Review, 1995: 255.

Kopylov, O.B., 2014. Zalog denezhnykh sredstv kak sposob obespecheniya ispolneniya obyazatelstv po dogovoru. Zakonodatelstvo i ekonomika, 5: 45-48.

Oskina, I.Y. and A.A. Lupu, 2012. Osobennosti zaloga imushestvennykh prav cherez prizmu konstruktsii "pravo na pravo". Yurist, 6: 1721.

Oxford Dictionaries. Language matters. Date Views 16 November 2014 http://www.oxforddictionaries.com.

Rybalov, A.O., 2013. Osobennosti zaloga v lombarde. Moskovskiy yurist, 5: 25-33.

Search Legal Terms and Definitions. Date Views 16 November 2014 http://dictionary.law.com

Stepanchenko A.V., 2013. K voprosu o zaloge beznalichnoy inostrannoy valyuty. Bankovskoe pravo, 5: 25-33.

Tetiouchev, D. and D. Shaklein, 2014. Overview of the amendments to Chapter Four the Russian Civil Code. Legal Alert.

Zimmermann, R., 1990. The Law of Obligations. Roman Foundations of the Civilian Tradition. Juta \& Co, Ltd, pp: 220.

What is The Difference Between Collateral and Mortgage. Date Views 16 November 2014 http://whatis.thedifferencebetween.com/ compare/collateral-and-mortgage/. 